\title{
Library Service Innovation in The Department of Archives and Library of Bandung District
}

\author{
Diva Thea Theodora Ismail ${ }^{1}$, Rosiana Nurwa Indah ${ }^{2}$, Rifqi Zaeni Achmad Syam ${ }^{3}$ \\ ${ }^{1,2,3}$ Universitas Islam Nusantara \\ e-mail: divatheodora11@gmail.com ${ }^{1}$
}

\begin{abstract}
Article Info
Article history:

Received

September $17^{\text {th }}, 2021$

Revised

December $3^{\text {th }}, 2021$

Accepted

December $4^{\text {th }}, 2021$

Published

January $1^{\text {th }}, 2022$

\section{Abstract}

The Bandung Regency Archives and Libraries Service is one of the regional public libraries of Bandung Regency which has service innovations during the COVID-19 pandemic. The Bandung Regency Archives and Library Service provides a mobile user interface service named $i$-Sabilulungan. The purpose of this study was to determine the usefulness of the $i$-Sabilulungan application as a service innovation during the COVID-19 pandemic at the Bandung Regency Archives and Library Service. The research method used in this research is descriptive qualitative research method with data collection techniques through observation and interviews. In this study, the informants were librarians managing the i-Sabilulungan mobile application. The results of this study reveal that $i$-Sabilulungan as a library service innovation for the Bandung Regency Archives and Libraries Service has fulfilled an important element in the application of the mobile user interface application. The i-Sabilulungan application has fulfilled 10 elements of the application of the mobile user interface application which consists of several elements including connectivity, simplicity, directional, informative, interactivity, user friendliness, comprehensiveness (completeness), continuity (sustainable), personalization (personalization) and internal elements (internal).
\end{abstract}

Keywords: public library; library service innovation; library mobile application; user interface

\footnotetext{
Abstrak

Dinas Kearsipan dan Perpustakaan Kabupaten Bandung merupakan salah satu perpustakaan umum daerah Kabupaten Bandung yang memiliki inovasi pelayanan pada saat pandemi COVID-19. Layanan Arsip dan Perpustakaan Kabupaten Bandung menyediakan layanan antarmuka pengguna ponsel bernama i-Sabilulungan. Tujuan dari penelitian ini adalah untuk mengetahui kegunaan aplikasi iSabilulungan sebagai inovasi layanan pada saat pandemi COVID-19 pada Dinas Arsip dan Perpustakaan Kabupaten Bandung. Metode penelitian yang digunakan dalam penelitian ini adalah metode penelitian kualitatif deskriptif dengan teknik pengumpulan data melalui observasi dan wawancara. Informan dalam penelitian ini adalah pustakawan pengelola aplikasi i-Sabilulungan mobile. Hasil penelitian ini mengungkapkan bahwa i-Sabilulungan sebagai inovasi layanan perpustakaan pada Dinas kearsipan dan Perpustakaan Kabupaten Bandung telah memenuhi salah satu elemen penting dalam penerapan aplikasi mobile user interface. Aplikasi i-Sabilulungan telah memenuhi 10 elemen aplikasi aplikasi mobile user interface yang terdiri dari beberapa elemen diantaranya konektivitas, simplicity, directional, informative, interactivity, user friendliness, comprehensiveness (kelengkapan), kontinuitas (sustainable), personalization (personalisasi) dan elemen internal (internal).
}

Kata Kunci: perpustakaan umum; inovasi layanan perpustakaan; aplikasi mobile perpustakaan; antarmuka pengguna 


\section{INTRODUCTION}

At the end of 2019, the World Health Organization (WHO) revealed to the world that there is a new virus finding, Coronavirus Disease (COVID-19). The Covid-19 virus is a new type of virus originating from Wuhan China that has spread to several countries in the world including Indonesia. As of January 5, 2021, the number of Indonesians who are positively affected by the COVID-19 virus is 779,548 people (Pramudiarja, 2021). The large number of people infected with the COVID-19 virus makes demands on changes in people's living order by implementing various health protocols aimed at minimizing the prevention of transmission of the COVID-19 virus. Minimizing the transmission of the COVID-19 virus, the Indonesian government issued several recommendations, namely the application of $3 \mathrm{M}$ (washing hands, wearing masks and keeping a distance); closure of public services; tourist attractions; reduce the density of workers in the industrial sector by implementing work from home to minimize the transmission of the COVID-19virus. In minimizing the transmission of the COVID-19 virus, the Indonesian government issued several recommendations, namely the application of 3M (washing hands, wearing masks and keeping a distance); closure of public services; tourist attractions; reduce the density of workers in the industrial sector by implementing work from home to minimize the transmission of the COVID-19 virus.

Libraries as public service providers in the form of providing information are ultimately also affected. Libraries are unable to perform their roles and functions to the fullest due to the COVID-19 virus. The presence of the COVID-19 virus has a significant impact on all activities in the library. Not a few libraries choose to physically close access to their services or impose restrictions on visiting musicians by complying with applicable health protocols. The urge to keep distance and work from home makes all activities in the library can not run to the maximum. Therefore, in the era of the COVID-19 pandemic, it becomes a challenge for libraries, namely libraries are required to innovat provide maximum and optimal services in meeting the needs of information pemustaka. To be able to meet the needs of musicians during the COVID-19 pandemic libraries can innovate by providing digital services. In addition, libraries can provide online-based services to be accessible to all library users without any space and time restrictions during the COVID-19 virus pandemic.

Digital library is one of the solutions that can be done during the COVID-19 pandemic as it is today.
Hartono (2016) revealed that digital library is a library environment that provides remote access facilities and contains various objects of information whether it is in the form of documents, sounds and video clips that are stored and accessible in digital form. Aisyiyah (2019) revealed that many libraries are currently developing digital libraries based on mobile library applications with the aim of making it easier for users to reach and access library services. The large number of smartphone users among the public makes the opportunity for libraries to develop application-based digital libraries Digital library is one of the solutions that can be done during the COVID-19 pandemic as it is today. The large number of smartphone users among the public makes the opportunity for libraries to develop application-based digital libraries.

Bandung Regency Archives and Library Office is a public library of Bandung Regency located on Jalan Raya Soreang KM.17 Bandung District Government Complex. In the current era of the COVID-19 virus pandemic, the Bandung District Archives and Library Office was forced to close public library access and stop all library activities in order to prevent the transmission of the COVID-19 virus. However, the COVID-19 pandemic did not stop the efforts of the Bandung District Archives and Library Office to continue to meet the needs of the library by providing excellent services to the musicians. Bandung District Archives and Library Office innovates and transforms from physical services to digital services in order to meet the needs of its musicians. In addition, the Bandung District Archives and Library Office facilitates the library by providing online-based services that can be reached by all people of Bandung Regency. Innovation and transformation conducted by the Bandung Archives and Library Office is to provide a digital library mobile application that can be accessed by all people of Bandung Regency, namely i- Sabilulungan. i-Sabilulungan is a digital library mobile application created by the Bandung District Archives and Library Office. i-Sabilulungan is digital library mobile application based on social media that can be used to read the digital collection that is in the application. iSabilulungan can be accessed through smarthphone both android and iOS. The user interface (UI) in the i-Sabilulungan mobile app is basically attractive with a design and layout that attracts users to read it. In addition, on mobile i-Sabilulungan there are many features that can be utilized by its users. Based on this background, the author is interested in researching how the service innovations that have been done by the Bandung District Archives and Library Office if 
Diva Thea Theodora Ismail et al, Library Service Innovation in The Department of Archives ...

reviewed from the User interface (UI) owned.Thus the research is titled "Innovation Of Library Services In The Era Of The Covid-19 Pandemic In The Archives And Library Office Of Bandung Regency (Case Study Of I-Sabilulungan Service)".

Based on the results of the search conducted by the author, found some literature that has a connection with the discussion studied, including:

\section{Regional Public Libraries}

The library is a place for information providers. Indah (2019) revealed that the library is the center of information sources and becomes the center of information development that is useful in fulfilling the information needs of its users in the fields of education, research, preservation, information and recreation of the musicians. Rahayuningsih (2013) revealed that a public library was established to serve all members of the public who need information services and libraries.

\section{Library Services}

As one of the information providers, libraries must be able to provide and provide services to libraries without exception including public libraries. Public library is a library established by the government for the general public to support the learning of the general public. As a public library, the Bandung District Archives and Library Office has a significant role in educating and improving the intellectual community of Bandung Regency. In supporting efforts to educate the nation's life by providing several services. Safitri, et al (2020) revealed that in general libraries have several services, namely:

1. Library orientation service, where the library provides information about collections available in libraries, services and information tracing in general that is usually carried out periodically

2. Circulation service, in this service visitors can borrow and return the collection materials

3. Reference services, this service contains a collection of reference materials

4. Deposit service is a collection of library materials issued by the government and non-government to comply with the law on the handover of Indonesian record works and printed works

5. Tandon Book Service is a collection of library materials or the first collection of copies that can only be read on the spot

6. Audio visual collection service

7. Special services consisting of special collections such as thesis, proceedings, thesis and others
8. Library search service divided into two ways, namely through the internet and CD-ROM

9. Reproduction services such as photocopying, index creation and abstracts

10. Cooperation services between libraries.

\section{Digital Library}

Hartono (2016) revealed that digital libraries provide a wide variety of knowledge sources, providing users with relevant source discovery mechanisms. Based on the above opinion, it can be known that the digital library is a library information system that contains a variety of digital-based services that can facilitate the library in utilizing it without any restrictions on space and time. Based on the above opinion, it can be known that the digital library is a library information system that contains various services and collections of digital-based library materials that can be accessed by library users. By Subrata (2009) revealed that there are several things that need to be considered when digitizing the library, including:

1. The development of Information and Communication Technology is growing and becoming an opportunity for information technology libraries that are cheap and easy to apply to libraries in Indonesia.

2. Library is an institution that has educational, informative, preventive and recreative functions that are translated as scientific activities, places of search for data or authentic information, storage places, seminar venues, scientific discussion venues, educhatid and contemplative recreation places for the public at large.

3. The existence of digitalization facilities in the library makes the collection available in the library can be read and utilized by the public.

4. The volume of library work that will be light with the digitization of the library.

\section{Library Mobile Application}

Fatmawati (2012) revealed that the mobile library or M-Library is a combination of mobile devices and libraries that serve to assist the library in informing existing services and assisting the library in accessing the services in the library. i-Sabilulungan is an innovation of digital library services issued by the Bandung Archives and Library Office. i-Sabilulungan is a digital library service based on mobile applications that can be accessed via smartphone. i-Sabilulungan can be downloaded through android or iOS system. During the Covid-19 pandemic, i-Sabilulungan is 
a solution for those who want to make easy use of their library collection by accessing it through their smartphone.

\section{User Interface (UI)}

User Interface (UI) is an interface view on users with devices. According to Mora (2015) revealed that the user interface (UI) is a layout design of the interface between the user and the screen of a mobile device or smartphone. In line with the above opinion, Roger and Bruce (2015) revealed that through the user interface (UI) can facilitate effective communication media for humans with computers. Based on the opinion of the above experts, it can be known that the user interface (UI) is a display designed to be a medium of communication between users and mobile devices. Rouse (2015) revealed that in the mobile user interface (UI) there can be interaction between users and applications through the features, content and functions of the device in the application. Aisyiyah (2019) argues that the user interface (UI) is a layout or design of the application display on a smartphone mobile device screen that facilitates the use and operation of applications on mobile devices. Zamri (2015) revealed that in the mobile user interface (UI) there are 10 most important elements, including:

1. Conectivity: Meets user needs.

2. Simplicity: Information must be minimalistic or simple due to limited user attention.

3. Directional: Interaction and clear sequence of actions

4. Informative: The information is needed and important

5. Interactivity: Navigation used is simple but clear and easy to use

6. User Friendliness: The design or layout of the layout and language used are easy to understand

7. Comrehensiceness:Can be widely used.

8. Continuity: Consistency in position and against similar actions.

9. Personalization: Users can control and there is support for it.

10. Internal: Flexibility on both small and large screens and prevent design errors.

\section{METHOD}

The research method used in this study is descriptive research with qualitative approach. In this study using data collection techniques by means of observations and interviews. The informant interviewed amounted to 3 (Three) informants who are librarians managing i-Sabilulungan in the Archives and Library Office of Bandung Regency. The following information informants in the study, namely:

Tabel. 1 Informant

\begin{tabular}{cccc}
\hline No & Name & Age & Gender \\
\hline 1 & Mr. Rengga & 32 th & Male \\
2 & Mrs. Mimin & 36 th & Female \\
3 & Mr. Yusman & 38 th & Male \\
\hline
\end{tabular}

In addition, the study used the Data Analysis Techniques of the Miles and Huberman Model. According to Miles and Huberman (in Sugiyono, 2020) revealed that all activities in qualitative data analysis are conducted interactively and continue continuously until complete, so that the data obtained is saturated. The steps in data analysis include:

1. Data Collection

2. Data Reduction

3. Data Presentation

\section{RESULTS AND DISCUSSION}

i-Sabilulungan is a digital library mobile application from the Bandung District Archives and Library Office. i-Sabilulngan is a digital library mobile application based on social media. The following features are available in i-Sabilulungan, including:

\section{Registrasi/ Sign Up}

Registration / Sign Up in order for the user to access i-Sabilulungan, the user must register first. This is so that the user can be registered as a member of i-Sabilulungan user so that the user can borrow and read books on the i-Sabilulungan app.

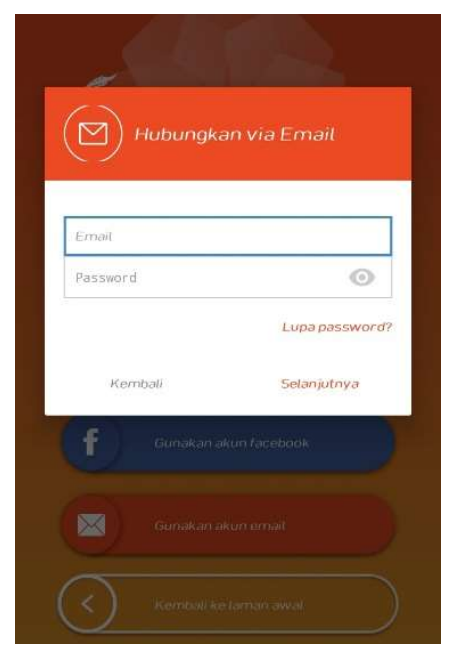

Figure 1. i-Sabilulungan Application Registration Display

(Source: Researcher, 2020) 
Diva Thea Theodora Ismail et al, Library Service Innovation in The Department of Archives ...

\section{Dashboard}

Dashboards are the main look on i-sabilulungan. In this dashboard consists of several features.

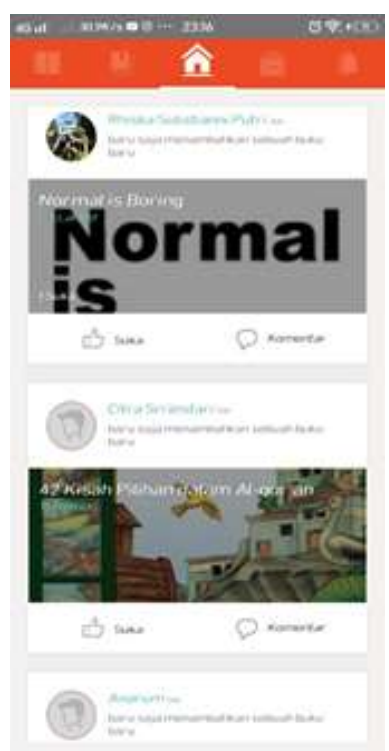

Figure 2. i-Sabilulungan Application Dashboards Display

(Source: Researcher, 2020)

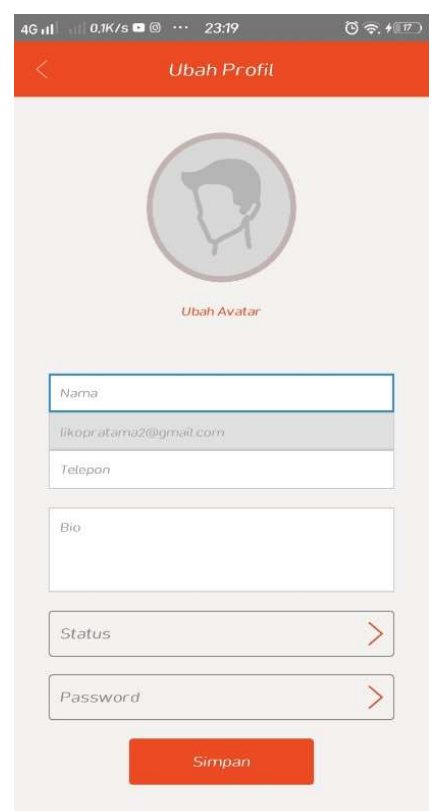

Figure 3. i-Sabilulungan Application Profile Display (Source:Researcher, 2020)

Profile Setting is a profile account setting feature where in this feature there is user personal data such as user username, email address, live in, password, user biography. In addition, users can also add photos to their account avatar.

\section{Notification}
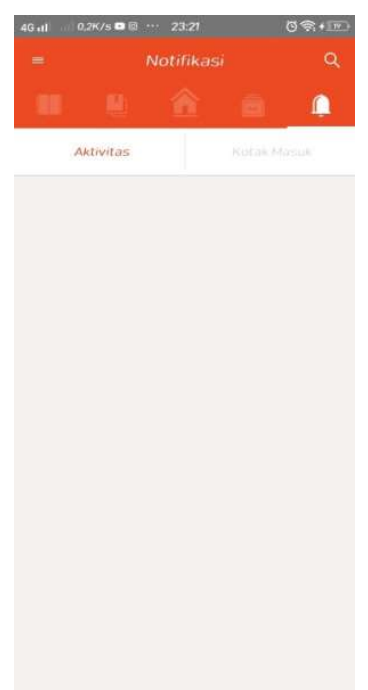

Figure 4. i-Sabilulungan Application Notification Display

(Source:Researcher, 2020)

Notification is a feature that contains the user's personal notification information, such as comments, share-recommend, New Followe, Badges status, messages and likes.

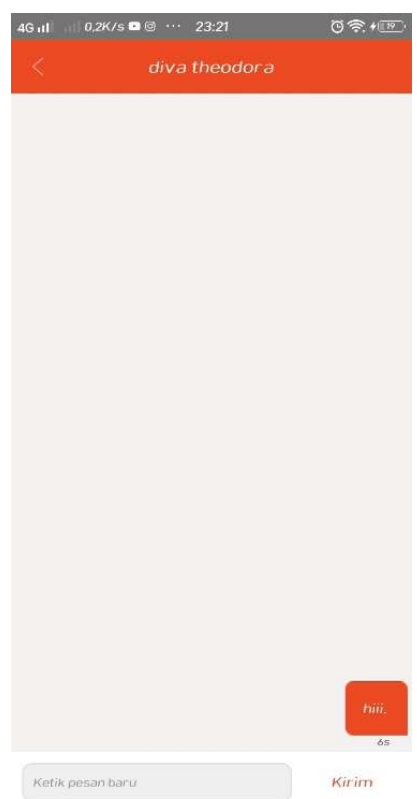

Figure 5. i-Sabilulungan Application Inbox Display (Source: Researcher, 2020)

Inbox is a feature that users can use to establish communication and interact with other users. 


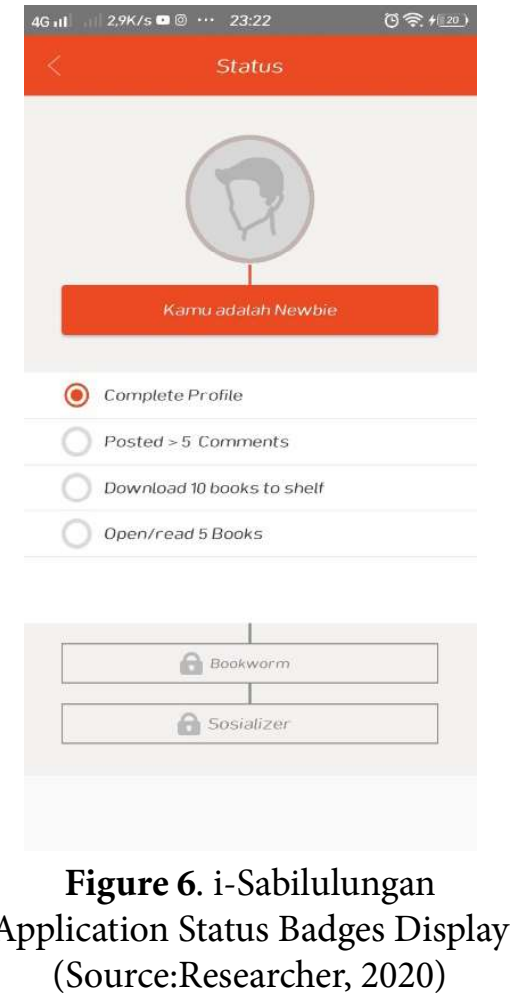

Badges status is a feature that contains about the read level of i-Sabilulungan users. There are several reading levels in i-Sabilulungan namely Newbie to Bookworm and Socializer. For users who want to level up, the user must meet several predefined criteria, Including:

\section{Beginner Level (Newbie to Bookworm)}

At this entry level the criteria is users who have completed the profile, submitted comments 5 times, users have downloaded books as many as 10 times on their shelves, and users who have opened / read 5 books.

\section{Bookworm to Socializer}

The criteria of the Bookworm to Socializer reading level are users who already follow 10 other users, recommend 5 reading books and users should have 10 followers.

Book Finish is a feature that contains a collection of books that have been owned. In the book to finish also contains information on the percentage of book reading and the deadline for borrowing books.

\section{Followers/Following}

Followers/Following list in this feature users can see the list of followers and the list of other users who followed.

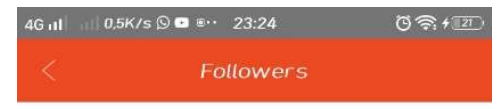

Figure 7. i-Sabilulungan

Application Followers Display

(Source:Researcher, 2020)

\section{Store}

The store in this view contains a catalog of books contained in the i-Sabilulungan app. In this store page there are several other features.

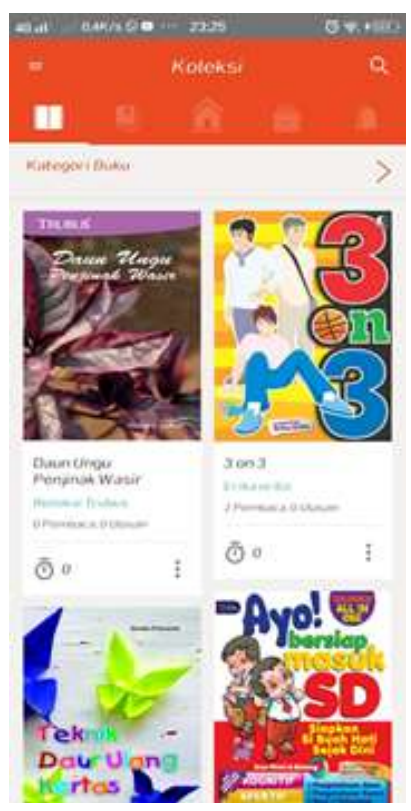

Figure 8. i-Sabilulungan

Application Store Display

(Source:Researcher, 2020)

Search Book is a feature that can be used to perform the necessary book searches using keywords. For example, searching for "math" books, after a click will automatically exit some book titles that contain a discussion about the keywords in search.

Book Category is a feature used to search for books by existing categories. In i-Sabilulungan there are several categories, namely general books, magazines and comics.

\section{E-Pustaka}

E-Pustaka is a feature that contains a collection of publishing agencies in collaboration with i-Sabilulungan. For example, when the user wants to find pustakamaya publisher on e-library, there will 
Diva Thea Theodora Ismail et al, Library Service Innovation in The Department of Archives ...

appear some features such as follow epustaka, list book, list followers, list comment and join e-pustaka.

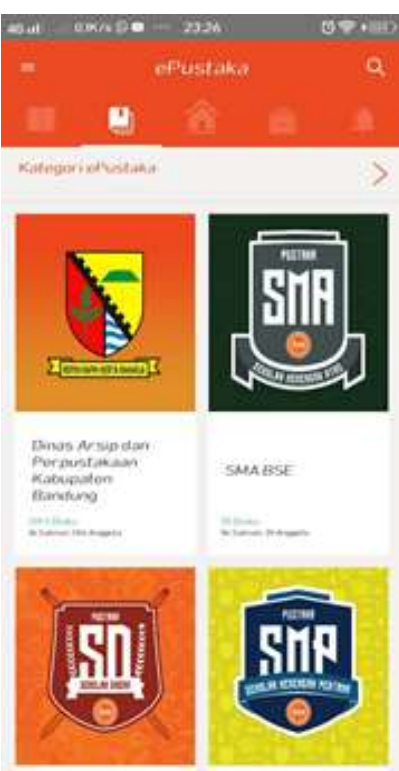

Figure 9. i-Sabilulungan Application E-Pustaka Display

(Source:Researcher, 2020)

\section{Book Detail}

Book Detail is a feature that contains the cover and bibliographic detail information of a book. In this feature, users can also find out the rating of the book, the price of the book and the synopsis of the book. In addition, users can see who wants the book, read it and who has finished reading the book.

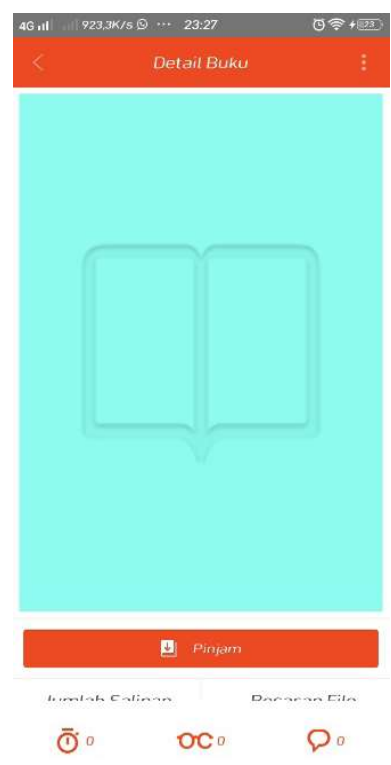

Figure 10. i-Sabilulungan Application Book Detail Display

(Source:Researcher, 2020)

\section{Share}

Share is a feature used to share info about book details. Users can also share it via facebook, twitter, email and others.

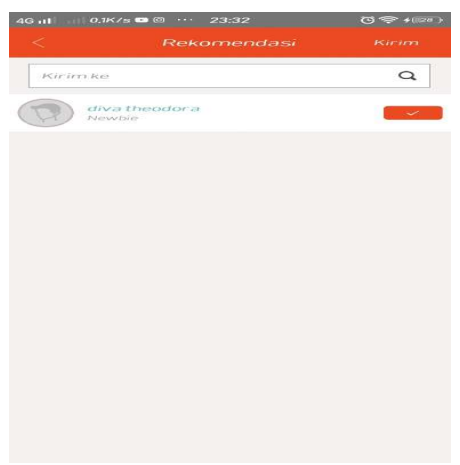

Figure 11. i-Sabilulungan

Application Share Display

(Source:Researcher, 2020)

Shelf

Shelf is a collection of collections that already own, collections that you want, as well as containing collections that have been read.

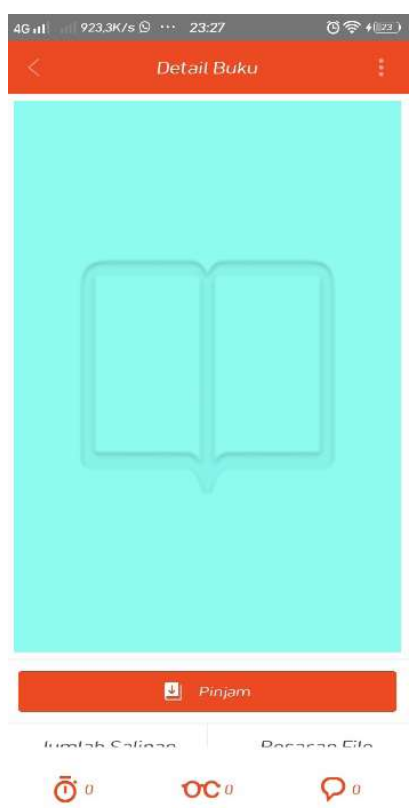

Figure 12. i-Sabilulungan Application Shelf Display (Source:Researcher, 2020)

\section{E-Rider}

E-Rider is a feature that users can use to read books that are equipped with a table of contents of the book to be read. 
Feed

Feeds are a collection os information that is public. In this Feed contains information such as other users who add books, users who recently joined e-Library and so on.

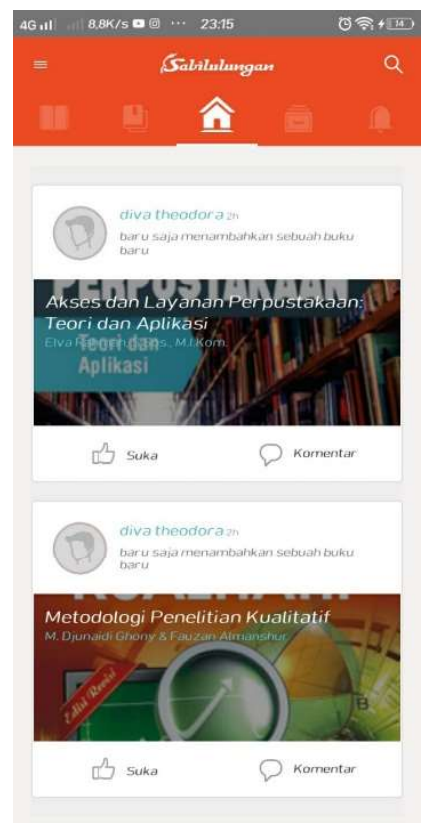

Figure 13. i-Sabilulungan Application Feed Display (Source:Researcher, 2020)

As one of the mobile applications based on user interface (UI), i-sabilulungan facilitates users to interact with the application. Through the user interface (UI) users can know the capabilities and usability in the application. Zamri (2015) explained that in the implementation of a mobile user interface (UI) there are 10 elements. The following is the implementation of 10 important elements in the implementation of user interface (UI) in i-Sabilulungan application.

\section{Conectivity}

i-Sabilulungan as a digital-based information provider has basically met the needs of users. In this case, i-Sabilulungan has provided a variety of ebooks on the i-Sabilulungan app. In i-sabilulungan there are 2,881 titles and 36,000 copies. The types of ebooks available are also very diverse ranging from science, applied science to comics and novels are also provided on i-Sabilulungan. In addition, based on data on the playstore in 2021 it is known that i-Sabilulungan has been downloaded more than 1,000 downloaders. This can prove that through i-Sabilulungan users can meet the need for information. In addition, the features in i-Sabilulungan can also meet the user's need for the information needed. For example, there is an ebook lending feature which allows for users to borrow and read e-books as needed. The informants who are librarians managing i-Sabilulungan revealed that so far i-Sabilulungan has made it easier for users to provide digital reading services. The existence of i-Sabilulungan makes it easier for users to access all the information they need without visiting the library.

\section{Simpility}

Based on the results of interviews with informants argue that the Archives and Bandung District Office has been trying to facilitate the public in utilizing the library through the i-Sabilulungan application. i-Sabilulungan is designed with simplicity in mind so that this application can be accepted among the public. i-Sabilulungan has simple and easy-to-use features for its users. By having simple and easy-to-use features, users can use this i-Sabilulungan application effectively and efficiently.

\section{Directional}

In the use of i-Sabilulungan application has a directional flow where the interaction and sequence of actions are clear. The wording of i-Sabilulungapun is quite concise and clear. The informants revealed that in the use of i-Sabilulungan the wording and commands on each feature are made so concise and clear but contain complete information that the user understands every information and features available on i-Sabilulungan.

\section{Informative}

Bandung District Archives and Library Office provides i-Sabilulungan to meet the needs of users related to the information needed. i-Sabilulungan provides a variety of information needed by the library that can be accessed through the collection available. Informant revealed that in i-Sabilulungan all forms of tools and menus and collections in i-Sabilulungan are informative. For example in the detailed menu book feature where in the menu feature explains the bibliographic description of the book to the synopsis of the book that is packaged in a simple layout but provides complete information.

\section{Interactivity}

i-Sabilulungan is a social media-based mobile user interface (UI) application. Basically i-Sabilulungan already meets this element, where the navigation used in i-Sabilulungan has been made simple but clear so that it is easy to use. For example 
in the application i-Sabilulungan membership registration process is directed through simple but clear navigation such as by giving instructions to login first via email or facebook and then users can register membership by filling in identity such as name, NIK and so on. In addition, i-Sabilulungan can also be said to be responsive which has features that make it easier for users when there is trouble in accessing the i-Sabilulungan application. Based on the results of the interview, the informant revealed that $\mathrm{i}$-Sabilulungan is a responsive application where if in accessing i-Sabilulungan users experience difficulty then users can contact the admin through the inbox feature and directly the admin will help all the trouble experienced by the user.

\section{User Friendliness}

As a mobile interface application i-Sabilulungan is designed to facilitate users in utilizing the application. Based on the interview results, the informants revealed that in designing the design and features i-Sabilulungan pay attention to user-friendly concepts using symbols and language that is easy to understand by users. Thus allowing users to use i-sabilulungan more productively \& quickly.

\section{Comrehensiceness}

i-Sabilulungan is basically an application provided by the Bandung District Archives and Library Office for the people of Bandung Regency. However, the use of i-Sabilulungan is universal. Based on the interview results the informants revealed that i-Sabilulungan can be accessed / downloaded by anyone without any territorial restrictions. Thus it can be known that this i-sabilulungan can be used widely not only for the people of Kabuapten Bandung but can be accessed for all Indonesians. In addition, i-Sabilulungan also has a collection for all types of people, so that all types of people can access i-Sabilulungan ranging from children to parents.

\section{Continuity}

In this case, the design features in i-Sabilulungan are designed consistently from the membership registration process to the ebook search process. Having a consistent interface design certainly makes users do not have to bother to learn every different feature but have the same core.

\section{Personalization}

The ease of personalization settings in an application can improve the user's ability to use the system and encourage the role to actively understand the system more deeply. Based on the results of the interview, the informants revealed that in i-Sabilulungan users can control the system according to the user's wishes and the $\mathrm{i}$-sabilulungan application facilitates it by providing personalized features that can be controlled by the user itself. For example in the Follow/Following feature where users can set followers/follow other users as they see fit. In addition, there is a list book feature where in this feature users can include several ebooks that are used as a list for reading. Thus it can be said that the i-Sabilulungan application has implemented personalization elements in the application of the user interface (UI).

\section{Internal}

In this case, it relates to the flexibility of using the application. Flexibility is the ability of an application to respond to differences in users. Flexibility is done by providing various ways to access the i-Sabilulungan function, which can be said to be a flexible mobile user interface (UI) application where this application provides several options for users to access the application. The informants revealed that i-Sabilulungan can be accessed on various media devices ranging from desktops, PCs, netbooks, tabs and smartphones based on android and iOS. In addition, in accessing i-Sabilulungan on a smartphone, there are minimum specifications, including:

Minimum specifications for Android

- Have at least 1 GB of RAM

- Has a minimum screen of 4inch Minimum Specifications for iPhone / iPod:

1. iOS 7.0 or later required

2. Optimized for iPhone 6

3. Compatible for iPhone and iPod Touch

\section{CONCLUSION}

Based on the results and discussion above, it can be denied that the i-Sabilulungan mobile user interface (UI) application is the right innovation in the current COVID-19 pandemic. With the mobile user interface application, it makes it easier for users to access library collections at the Bandung Regency Library and Archives Service. Through the i-Sabilulungan application, users can access the library facilities of the Bandung Regency Archives and Library Service only by using their own mobile device or smartphone. As a mobile user interface application, i-Sabilulungan has fulfilled the 10 important elements in implementing the user interface. 
Where i-Sabilulungan has implemented elemental connectivity, simplicity, directional, informative, interactivity, user friendliness, comrehensiceness, continuity, personalization and internal.

\section{ACKNOWLEDGEMENTS}

Thank you to the archives and libraries of Bandung Regency, Nusantara Islamic University, Archipelago Islamic University Library Science Study Program and the Faculty of Communication Sciences, Nusantara Islamic University.

\section{REFERENCES}

Ahmadi, R. (201 6). Metodologi Penelitian Kualitatif. Yogyakarta: Ar-Ruzz Media.

Aisyiyah, B. M. (2019). Analisis User Interface Dalam Aplikasi Mobile . Pustaka Ilmiah,5(1), 726735. Retrieved January 3, 2021, from: https:// ejournal3.undip.ac.id/index.php/jip/article/ download/22810/20855.

Fatmawati, E. (2017). Pemanfaatan Aplikasi Perpustakaan Digital iJateng Melalui Smartphone. Profetik Jurnal Komunikasi, 10(2), 46-56. Retrieved January 3, 2021, from: https://media.neliti.com/media/ publications/224274-pemanfaatan-aplikasiperpustakaan-digita.pdf.

Hartono. (2016). Manajemen Perpustakaan Sekolah. Yogyakarta: Ar-Ruzz Media.

Indah, R. N. (2019). Kontribusi Lembaga Informasi di Era Disrupsi dan Globalisasi. N-Jils, 79-92.Diakses pada: Recieved January 4, 2021, from: http://ojs. uninus.ac.id/index.php/JILS/article/view/518/345

Mora, S. L. (2015). Human-Computer Interaction. Spanyol: Universidad de Alicante ISI. Retrieved January 4, 2021, from: http://desarrolloweb.dlsi.ua.es/ cursos/2015/hci/user-interface-design

Octaviani, A. (2019). Penggunaan Mobile Library untuk Perpustakaan Digital. ANUVA, 3(2), 151-155. Retrieved January 4, 2021, from: https://ejournal2. undip.ac.id/index.php/anuva/article/view/5234
Pramudiarja, A. U. (2021). Update Corona Indonesia 5 Januari: Tambah 7.445, Total Positif 779.548 Kasus. Jakarta: Detikhealth.Retrieved January 5, 2021, from: https://health.detik.com/beritadetikhealth/d-5321896/update-corona-indonesia5-januari-tambah-7445-total-positif-779548-kasus

Safitri, R, dkk. (2020). Inovasi pelayanan perpustakaan melalui taman bacaan masyarakat Jatmika Jawa Barat menghadapi Covid-19. N-JILS, 3(2), 266-282. Retrieved January 5, 2021, from: http://ojs.uninus. ac.id/index.php/JILS/article/view/1047

Subrata, G. (2009). Perpustakaan Digital. Pustakawan Perpustakaan UM, 1-11. Retrieved January 3,2021, from: http://digilib.um.ac.id/images/stories/ pustakawan/kargto/Perpustakaan\%20Digital.pdf

Sugiono. (2020). Metode Penelitian Kuantitatif, Kualitatif dan R\&D. Bandung: Alfabeta.

Rosiyan, N. (2020). Layanan Perpustakaan di Era Pandemi Sebagai Implementasi Industri 4.0: Studi Kasus PDDII LIPI. Ilmu Perpustakaan dan Informasi,5(2), 118-131. Retrieved January 5, 2021, from: http://jurnal.uinsu.ac.id/index.php/jipi/article/ view/8366/3901.

Rouse, M. (2015). Mobile UI (Mobile User Interface). TechTarget. Retrieved January 3, 2021, from: https:// searchmobilecomputing.techtarget.com/definition/ mobile-UI-mobile-user-interface

Yuliani, T. (2017). Pengembangan E-Library dalam meningkatkan pelayanan perpustakaan IAIN Batusangkar. Al-FUad, 1(1), 16-31. Retrieved January 3, 2021, from: https://core.ac.uk/download/ pdf/236393064.pdf.

Zamri, K. Y. (2015). 10 User Interface Elements For Mobile Learning Application Development. International Conference on Interactive Mobile Communication Technologies and Learning (IMCL), 48-49. Retrieved January 5, 2021, from: https://ieeexplore. ieee.org/document/7359551/authors\#authors

Prastowo, A. (2016). Metode Penelitian Kualitatif Dalam Perspektif Rancangan Penelitian. Yogyakarta: ArRuzz Media. 